\title{
ストーマ造設術が及ぼすオストメイトQOLへの影響と外科医の責任 後編：オストメイトQOL全国調查解析
}

近畿大学メデイカルサポートセンター ${ }^{1)}$, 大阪市立総合医療センター泌尿器科 ${ }^{21}$ 進藤 勝久 ${ }^{1)}$ 上川 禎則 ${ }^{2)}$

\section{内容要旨}

【目的】オストメイト調査票を集計して, 背景因子とQOLの関係をみる. その結果から, 手術の工 夫や術後ケアについて考察する.

【方法】改訂QOL調査票による全国オストメイト 2,200 人のデータから，各因子の相関関係やストー マのQOLへの影響をみる。統計学的有意性を検討して，臨床経験・証拠を基に検証した。

【結果】統計学的解析では, 一般人と比較してオストメイトの身体, 社会, 生活の各機能スコアは 有意に低かったが, 心の健康はやや低く, 活力や健康感は高い傾向にあった. 患者会所属者は心理的 問題に悩むことが少なく，ストーマ関連の問題も少ない．家計負担は，周囲皮膚障害，運動や睡眠や 衣服選択に問題を持つ人が関連していた.

【結論】外科医はストーマ造設術後の患者個人の日常や社会活動にも関心を持って，ストーマ術式 やケアを工夫すべきである。

索引用語: QOL, オストメイト, 人工肛門, 尿路変向術, ストーマ・リハビリテーション

\section{緒 言}

本邦には人工肛門造設術や尿路変向手術を受け た結果, 腹壁にストーマを保有することになった 患者（以下，オストメイトという）で，身体障害 者手帳を所持する者は約 204,000 人もいる ${ }^{1)}$. その 全国患者団体としては唯一「公益社団法人日本才 ストミー協会」(JOAと略す) があり，数年毎に 7 回も，所属会員の実態を報告してきたが，医学的 観点から彼らの生活の質（以下, QOLという) は 取り上げられていない.

QOLの概念は前編で述べたが，この多次元で包 括的な個人的自覚をいかに分析して, 医療者の視 点から, 患者のQOL向上に寄与できるかを考えて みたいものである. 多くのQOL研究は単に分析結

受付：2018年 1 月 22 日, 採用：2018年 3 月 13 日 連絡先 進藤勝久

干589-0023 大阪府大阪狭山市大野台 7-13-4 近畿大学メディカルサポートセンター
果に満足しているだけで，あるいは実態を供覧し ているだけで，臨床的に還元できていない．

前編でコロストミー（以下，コロという）用の QOL調査票を全ストーマ用に改訂した以上は, そ れを使用することによって得られた情報を統計学 的に処理し, 外科系医師 (以下, 外科医という) としての解釈と, それに対する外科医としてのケ アについて考察していく.さらに, その結果から 生じる手術方法や術後管理・ケアで改良すべき点 や，追究するべきものがあれば，それらを進化さ せていくことが必要である.

ここに，オストメイトQOL調査票改訂版（以下， 改訂版という）を利用して，臨床的還元に寄与す る分析ができるかどうかを試みる次第である.

\section{対象と方法}

1 ）全国規模でこの改訂版QOL調查を実施する にあたっては, JOAの理事会と会誌編集委員会で 検討され, 会誌の真中に補遺 4 頁分の提供を受 け2)，ここに質問表の完成形を掲載した．その中の 
日本外科系連合学会誌 第 43 巻 6 号

Table 1 Category scores of short form- 8 by class

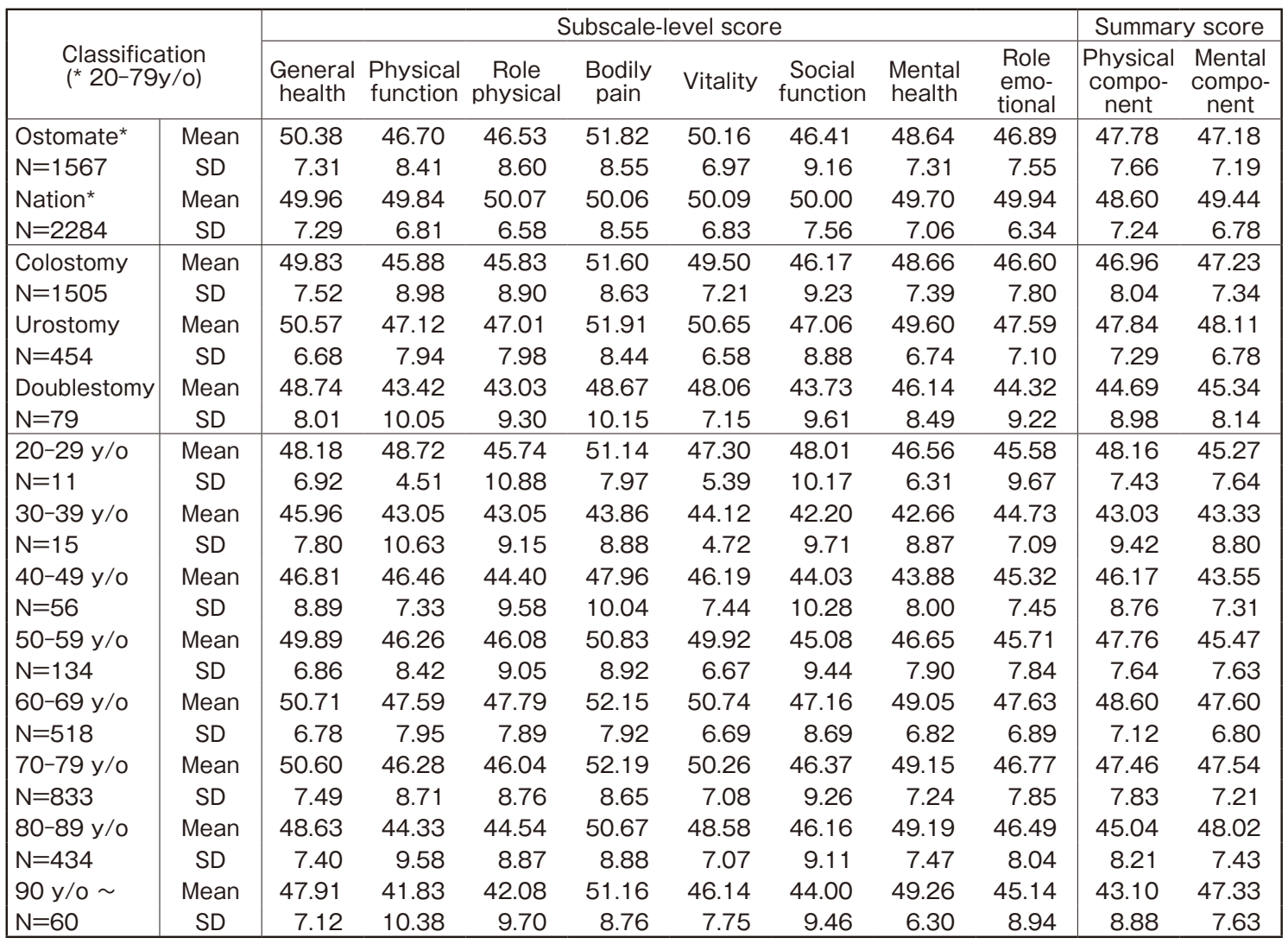

質問29は充実生活の理念 $(1 \sim 6)$, 問30は自由記 載項目であるため, 両者を本統計から除外した.

2) JOA以外の者（以下，非会員という）に対 する調查はほほ同時期に第 2 次対象者とし, 全国 各地で地方自治体が実施する社会適応訓練の患者 集会などで，患者の承諾を得たものに対してのみ 当該調査票を配布して, その場での記入又は後日 の郵送にて回収した。

3 ）締切りの 2015 年 7 月末に 1,860 通のJOA会員 からのQOL調査票を回収した。さらに8月末まで に集まった295通の非会員分を追加して, JOA会員 と非会員との有意差について検討する材料にした。 また，一般健康項目（SF-8）の集計結果から一 般健常人とオストメイトとの比較をした. 計算に はSF- 8 TM付属のスコアリングプログラム（NormBased Scoring）を使用しだ).

4 ）ソフトウェア「IBMのSPSS」と「エスミの EXCEL統計解析シリーズ」を使用して, 統計学的
分析を繰返し, 各質問項目と各背景因子との相関 関係を求めるとともに, 各種因子分析により, カ テゴリーの分別化を試みた $(p<0.01 を$ 有意とした $)$.

5 ) 単純に 2 因子間の比較のみで有意差を意味 づけるのは難しいと思われるので, 後述の多変量 解析を行った. また, 背景項目の中で, 統計学上 の実数が少なすぎる部分（稀有疾患など）や種類 が多岐にわたる場合（ストーマ部位・種類など） には，より大きな概念にまとめた。

6 ）単なる統計学的解析ではなく, 長年の臨床 経験を重視した客観的事実や根拠を無視しないこ とにした。

\section{1）一般健康項目}

\section{結 果}

一般健康の 8 質問で得られたデー夕を，身体的 サマリースコア (PCS), 精神的サマリースコア （MCS）を含めて, 年齢別, ストーマ種類別に, 統 計学的に算出した (Table 1). (1)同Table上闌の 
オストメイトQOL

Table 2 Ostomates' QOL scoring

\begin{tabular}{|c|c|c|c|c|c|c|c|c|}
\hline Factor & $\begin{array}{l}\text { Score } \\
\text { range }\end{array}$ & $\begin{array}{l}\text { Rough } \\
\text { score }\end{array}$ & Index & Mean & $\begin{array}{l}\text { Double } \\
\text { stomy }\end{array}$ & $\begin{array}{l}\text { Uros- } \\
\text { tomy }\end{array}$ & $\begin{array}{l}\text { Colos- } \\
\text { tomy }\end{array}$ & $\begin{array}{l}\text { lleos- } \\
\text { tomy }\end{array}$ \\
\hline PCS & $4-22$ & 16.6 & 4.56 & 75.78 & 68.9 & 77.5 & 74.8 & 75.4 \\
\hline MCS & $4-20$ & 15.1 & 5 & 75.75 & 68.7 & 77.9 & 74.6 & 75.1 \\
\hline Stoma Fact. & $9-36$ & 22.1 & 2.78 & 61.4 & 55.3 & 65.6 & 60.4 & 62.9 \\
\hline Psycolo F. & 8-32 & 22.7 & 3.13 & 70.9 & 66.0 & 73.0 & 70.3 & 73.7 \\
\hline Support F. & $4-16$ & 10.5 & 6.25 & 65.3 & 63.9 & 69.2 & 63.7 & 65.2 \\
\hline Social Fact. & $4-16$ & 8 & 6.25 & 50 & 45.6 & 53.3 & 52.6 & 57.7 \\
\hline Sexual Fact. & 3-12 & 7.5 & 8.33 & 62.4 & 56.5 & 62.5 & 62.7 & 62.0 \\
\hline Stress & $10-40$ & 25 & 2.5 & 62.5 & 56.3 & 66.8 & 60.2 & 63.0 \\
\hline Support & $2-8$ & 5 & 12.5 & 62.5 & 63.4 & 66.7 & 59.8 & 62.3 \\
\hline Satisfact & $2-8$ & 5.5 & 12.5 & 68.75 & 64.4 & 71.8 & 67.6 & 68.0 \\
\hline Physical & $2-8$ & 5.7 & 12.5 & 71.25 & 59.8 & 70.5 & 70.5 & 70.4 \\
\hline Activity & $4-16$ & 8.9 & 6.25 & 55.03 & 48.7 & 56.2 & 55.0 & 59.5 \\
\hline Mental & $5-12$ & 8.7 & 8.33 & 72.47 & 64.6 & 72.0 & 71.3 & 74.7 \\
\hline Self esteem & $2-8$ & 6.2 & 12.5 & 77.5 & 72.5 & 77.0 & 75.9 & 78.6 \\
\hline Sexuality & $3-12$ & 7.8 & 8.33 & 64.97 & 56.5 & 62.5 & 62.7 & 62.0 \\
\hline Economy & $1-4$ & 2.5 & 25 & 62.5 & 54.8 & 62.3 & 60.7 & 66.1 \\
\hline Total & $29-116$ & 75.3 & 0.86 & 64.76 & 58.4 & 66.4 & 63.0 & 65.5 \\
\hline
\end{tabular}

PCS=Physical Component Score, MCS=Mental Component Score

Rough score=Total mark points: Above shows total average

Index $=100 /$ Maximum of score-range

Mean=Rough score $\times$ Index

(Personal rough score $x$ Index)=Self score

同年齢層における日本国民標準值 ${ }^{4)}$ との比較では, オストメイトのPCS, MCSは国民標準值に比べて 低かったが, 有意差は認められなかった. (2)下位 尺度では, オストメイトの身体機能 $(\mathrm{PF})$, 社会 生活機能 $(\mathrm{SF})$, 日常生活機能; 身体 $(\mathrm{RP})$, 同; 精神（RE）は国民標準值に比べ有意に低かった. 有意差はないが, 体の痛み $(\mathrm{BP})$ と全体的健康感 (GH) と活力（VT）ではオストメイトが高点数 で, 心の健康 (MH) でわずかに低かった. (3)年 齢別のオストメイトと日本国民との比較では, 20 〜49歳のオストメイトのPCS, MCSが特に国民標 準值に比べ低かったが，高齢になるほど国民標準 值との差はなくなり, 50歳以上ではPCSが国民標 準值を上回った。 (4)ストーマ種類別では, PCSと MCSのサマリースコアのみならず, すべての下位 尺度項目でウロストミー（以下， ウロという）の QOLスコアが最もよかったのに対して, ダブルス トミー（以下，ダブルという）のいずれのスコア も最低であった。

\section{2) QOLスコア}

前述の一般健康項目と前編Table 6 で示したス
トーマ項目とを組み合わせてQOLスコアを計算し た結果を示す (Table 2). スコア算出方法は Table 2 の下に示した. 5 列目のQOLスコアの平 均值でみると, 身体健康PCSも精神健康MCSも同 点であるが, ストーマ項目では, 社会要因が最低 で, 心理要因が最高であって, 他の 3 要因には有 意差がない. ただし, 前編Table 6 下欄の様に細 分化してみると, 自尊心と心理状態は72点以上の 高点数であるが, 活動性は最低の55点であった (Table 2 下半部).

ストーマ種類別に比較してみたが (Table 2 右 半分), ウロはストーマ要因と支援要因では高点数 ながら, 心理要因と性的要因ではイレオストミー （以下，イレオという）と差がなかった. 社会要因 はイレオが最高点で, コロとダブルは低点数であっ た。

ストーマ総点が $25 \%$ 以下になった低群と $75 \%$ 以 上になった高群との間に介在するQOL要因につい ても統計学的に検討したが, 各質問項目では 1 前 後の差があっても，11. 家族・友人の支援, 12 . ストーマ外来・訪問看護, 24 . 思いやり・前向き 
価值観だけは，両群間に有意差があるとはいえな かった，つまり，この 3 点はQOLを左右する因子 とはいい難いことになる.

\section{3）相関関係と有意差検定}

背景因子10項目別にQOLに関係する37質問項目 一つ一つの有意差を検討した。性別や配偶者の有 無, 現行治療疾患の有無など 2 群間の有意差につ いては, Mann-Whitney U検定ならびにLepage検 定を行った。その他の有意差検定にはKruskalWalis検定ならびに多重比較法を用いた。その結果 を要約して1枚の表にした (Table 3)。なお,一 般健康スコア（Sf1～8） では，前述のようにオ ストメイトスコアに合わせるべく, QOL点数の変 換を行っている. 本来なら, 各デー夕因子点数を 示すべきであるが，膨大な資料表になるので，要 約表示にとどめた。

横軸に背景因子, 縦軸にQOL項目を羅列し, 有 意にQOLスコアの高いものを示す，なお，有意差 が出なかったものはTable 3 欄外に置いた，有意 差のある事項については, 従来の臨床経験からみ て納得のいくものか, また, 理由が説明できるか の観点から, 膨大な数值表を見ながら次の考察で 述べるが，ここでは主な事象を説明する。

2 群間有意差検定で, 配偶者（同Tableの 3 列 目）のある方にQOLスコアが有意に高かった項目 は，4.ストーマ音， 7 . 排泄処理， 11. 家族友 人, 16 . 水分摂取, 25 . 好奇心であり, Sf 5 . 活 力だけは配偶者のいない方が有意に高い.

次に多群間有意差検定では, 所属患者会（同 Tableの 4 列目Club）について, JOAや地域の会 や病院患者会に所属している者は, 他の患者会所 属者に比べるとSf 7 . 心の問題に悩まされること が少ない４４．ストーマ関連音についても気にな り難い。ただ，5，外見容姿への影響は他会所属 者に対しJOA会員のみで少ない.

ストーマの種類（同Tableの6列目）でみると, ダブルは, ウロよりもSf 7 . 心の健康, 2. ストー マ臭， 7. 排泄処理で困っていても，4. ストー マ関連音では優位に立っているのに対して, S状 結腸ストーマ（以下，シグマという）ょりも 16. 水分摂取と20. 睡眠では劣勢になっている。 また, ウロは, シグマ・イレオよりも2. ストーマ臭,
4. ストーマ音， 7. 排泄処理でQOL優位にあり，

16. 水分摂取ではシグマよりもQOL劣勢であるが, 20. 睡眠ではシグマが優勢で，イレオが劣勢であ る. なお， 16. 水分摂取ではイレオがシグマやウ ロよりも劣勢で, 水分をより必要としている. ダ ブルもシグマより16. 水分摂取が必要であった. 他方で, Sf 4。体の痛み, Sf 5。元気活力, Sf 7 . 心の健康，20. 睡眠では，イレオは，ウロやシグ マよりもQOL劣勢である。

術前説明者（同Tableの 4 列目 Expl）によるス コアの有意差を見ると，6．ストーマについて余 り恥ずかしく思わなくて済む率は医師説明の方が 看護師よりも高く, 看護師だけよりも医師も加わっ た方が高率という結果になっている．12．ストー マ外来や訪問看護への利用に関しては，医師と看 護師の両方から術前説明を聞いている方が，医師 説明だけより手軽に利用できる。ストーマを含む 医療についての14. 術前説明の満足度が高くなる のは，医師又は看護師だけよりも両者から説明を 聞いた場合である。

\section{考察}

本邦には膀胱・直腸機能障害登録者が，60歳未 満40,000人に対して，60歳以上が 164,000 人である ので1), 本調査回答者の人口比 220 人 : 1,850 人は高 齢者に 9 ポイントほど傾いている（日本 $80.4 \%$, 本 例 $89.4 \% ）$ が, 大差ではないので, 本調査結果は ほほ日本全体のオストメイトに敷衍できる.

日本外科系連合学会でも第20回総会以来, 又 トーマに関するシンポジウムやワークショップな どでも外科, 泌尿器科, 婦人科などの専門家討論 が行われてきた. 外科系医師としてのストーマ造 設術に対する責任をみるためには, 前編で記載で きなかったことも含めて, 背景因子間の問題につ いて考察したい.まず, 術後40年以上経過してい る者の, 原因疾患が「不明」や「その他」の者は $12 \%$ もり，このことは「40年以上前は悪性や難 病の疾患を本人に知らせない」ことが常識であっ たことを物語っている. 同様に, 術前説明者の変 化もインフォームドコンセント（以下ICと略す） の時代差であろう。つまり, 約 30 年前までは家族 や近しい人から説明を受ける割合が $12 \%$ もった し，無説明は14\%もあったが，それ以降はほとん 


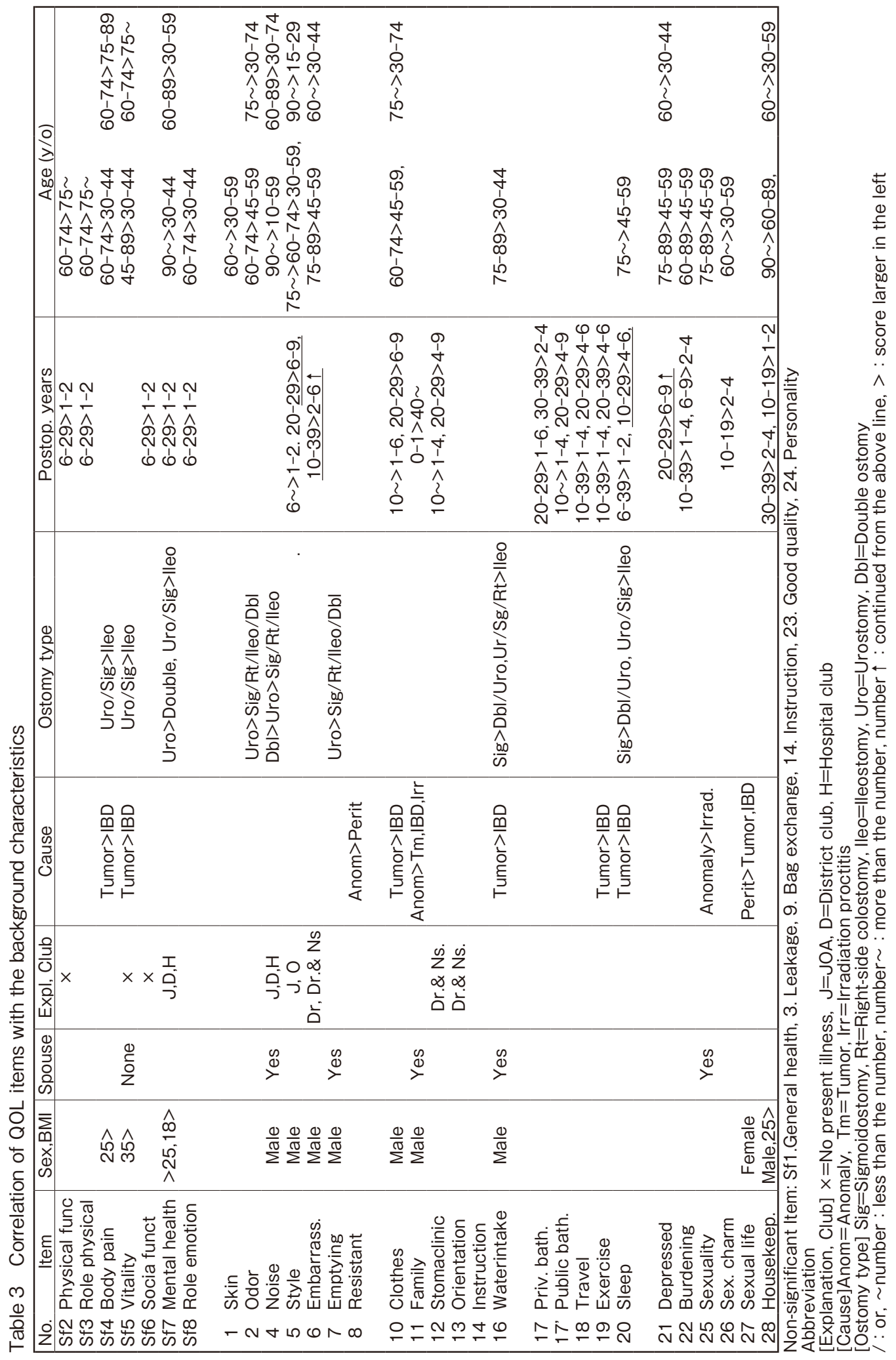


日本外科系連合学会誌 第 43 巻 6 号

Table 4 Satisfaction with preoperative orientation by explanation

\begin{tabular}{|c|c|c|c|c|c|c|c|c|c|}
\hline \multicolumn{2}{|c|}{$\begin{array}{l}\text { Expla- } \\
\text { nation }\end{array}$} & Surgeon & Nurse & $\mathrm{Dr} \& \mathrm{Ns}$ & Family & Others & None & $\begin{array}{l}\text { No re- } \\
\text { sponse }\end{array}$ & Total \\
\hline \multirow{6}{*}{ 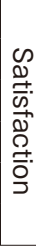 } & 1 & $91(7.4 \%)$ & 17 (9.5\%) & $13(2.7 \%)$ & 2 (13.3\%) & $9(36 \%)$ & 88 (54.7\%) & $2(5.7 \%)$ & $222(10.4 \%)$ \\
\hline & 2 & 379 (30.8\%) & 65 (36.3\%) & $128(26.7 \%)$ & $7(46.7 \%)$ & $10(40 \%)$ & 49 (30.4\%) & $8(22.9 \%)$ & $646(30.4 \%)$ \\
\hline & 3 & 507 (41.2\%) & $74(41.3 \%)$ & $215(44.8 \%)$ & $4(26.7 \%)$ & $3(12 \%)$ & $18(11.2 \%)$ & $16(45.7 \%)$ & 837 (39.4\%) \\
\hline & 4 & 242 (19.7\%) & 23 (12.8\%) & $120(25.0 \%)$ & $1(6.7 \%)$ & $3(12 \%)$ & $4(2.5 \%)$ & $8(22.9 \%)$ & $401(18.9 \%)$ \\
\hline & $X$ & $12(1.0 \%)$ & 0 & $4(0.8 \%)$ & $1(6.7 \%)$ & 0 & $2(1.2 \%)$ & $1(2.9 \%)$ & 20 (0.9\%) \\
\hline & * & $2.7(0.9)$ & $2.6(0.8)$ & $2.9(0.8)$ & $2.3(0.8)$ & $2.0(1.0)$ & $1.6(0.8)$ & $2.9(0.8)$ & $2.7(0.9)$ \\
\hline \multicolumn{2}{|c|}{ Total } & $1,231(57.9 \%)$ & 179 (8.4\%) & $480(22.6 \%)$ & $15(0.7 \%)$ & $25(1.2 \%)$ & $161(7.6 \%)$ & $35(1.6 \%)$ & $2,126(100 \%)$ \\
\hline \multirow{7}{*}{ 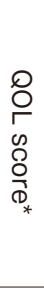 } & $P$ & 75.5 (17.6) & 73.3 (16.9) & $76.0(16.8)$ & $64.4(26.1)$ & 71.5 (18.0) & 73.5 (17.3) & $70.9(23.6)$ & 75.1 (17.6) \\
\hline & $\mathrm{M}$ & 75.4 (19.0) & 73.5 (18.4) & 75.7 (18.6) & $63.7(24.4)$ & 72.4 (19.2) & 73.5 (19.5) & 71.7 (24.3) & 75.0 (17.6) \\
\hline & St & $62.6(16.1)$ & $59.2(15.3)$ & 60.7 (15.8) & $51.1(22.1)$ & $55.7(13.5)$ & 59.9 (16.0) & $57.9(18.1)$ & $61.4(15.7)$ \\
\hline & Mf & 71.7 (14.9) & $67.7(15.0)$ & $71.4(15.5)$ & $56.8(15.2)$ & $67.7(15.4)$ & $69.1(15.5)$ & $65.0(15.7)$ & 70.9 (15.2) \\
\hline & $S p$ & $65.1(17.9)$ & $64.0(16.3)$ & 69.9 (17.3) & $60.0(22.1)$ & 58.5 (20.3) & $55.2(16.5)$ & $65.9(20.5)$ & 65.3 (18.0) \\
\hline & Sc & 53.9 (18.0) & 45.0 (16.9) & $52.2(17.8)$ & 42.5 (16.5) & 45.2 (14.3) & 51.4 (19.2) & $51.4(13.9)$ & $50, .0(18.7)$ \\
\hline & $S x$ & $62.4(21.0)$ & $61.4(20.4)$ & $62.5(22.4)$ & 50.5 (26.2) & $59.3(23.1)$ & 63.9 (21.9) & $66.4(26.6)$ & $62.4(21.6)$ \\
\hline \multicolumn{2}{|c|}{ Total } & 64.5 (13.2) & 61.5 (12.3) & $64.2(13.5)$ & $52.9(14.8)$ & 58.5 (12.6) & $61.4(13.1)$ & 62.4 (13.8) & 63.7 (13.3) \\
\hline
\end{tabular}

$X:$ None, ${ }^{*}:$ Mean (SD)

P: Physical component, M: Mental component, St: Stoma factor, Mf: Mental factor, Sp: Supportive factor Sc: Social factor, Sx: Sexual factor

ど医療者によって説明を受けている（前編 Table 4 )。ただ，約20年以上前までは医師のみの 説明が70\%前後で看護師の関与は少なかったが, それ以降は両者ともによく説明をするようになっ ている。本調査の生データでは，医師のみが $58 \%$, 看護師のみ $8.4 \%$, 両者からは $22.6 \%$ であった. そ こで，その13．満足度を分析してみた (Table4). 医師・看護師両方に説明を受けた方が術前説明に 最も満足している（4 点中の $2.9 \pm 0.8$ 点)という結 果になっている。 QOL各要因スケールでみると, 医師のみの説明ではストーマ要因, 心理要因, 社 会要因ならびにストーマ総点で最高得点を取って いるのに対して, 身体健康, 精神健康, 支援要因 では医師・看護師両者の説明によって最高点を 取っている. しかしながら, 性的要因は「説明者 なし」や「無回答」にQOLスコアが高いことから， 医療従事者の説明以上に自己処理しているものと 考えられる. 特に, 医・看両者の説明で最高満足 度 4 を獲得した率が高い（25\%）ことには有意差 があり, 看護師だけの説明では最高にはならなかっ た. 当然のことながら, 医療従事者以外の説明で はQOLスコアが有意に劣っていた。 また, 相関関 係では, 13. 術前説明の満足度と 14. ストーマ管 理の指導の満足度とは有意な相関関係にあること
も忘れてはならない（前編Table 8 )。医療従事者 間の連携も重要ではあるが, ここでは外科医の責 任をどのように果たすべきかを，Table 3, 4 と前 編Table 8 から考えてみたい.つまり, 外科医の 影響を強く受けるストーマ要因, 心理要因, 社会 要因については, 単に看護師に任せ放しにするの ではなく，手術に直接関わった外科医が自らの言 葉で患者を安堵させるような説明技術を身につけ るべきであろう。それには各地のストーマリハビ リテーション（SRと略す）講習会（3日間）や全 国SRリーダーシップコース（4 日間）の受講, あ るいは医師用に執筆された「SR学」 ${ }^{5)}$ が役立つこ とを期待する.

前編ではオストメイトの背景別にQOL分析をし たが,ここではQOL障害項目ごとに考察していく. まずは, 背景因子と有意差 $(p<0.01)$ がなかった 6 項目（Sf 1，3，9，14，23，24）について, オストメイトQOL医療では必ずしも重要視しなく てよいといえそうなものだが， 3. ストーマ漏れ， 9 . 装具交換, 14 . 管理指導は有意差限界 $(p=0.05)$ 付近にあるので，統計值よりも個人を重視した対 応が望まれる。統計的な患者評価よりも前述の 3 要因, 取分け「ストーマ要因」に関する適正な指 導が重要と思われる。具体的には後述する。 
$\operatorname{Sf} 2$. 身体機能やSf 3 . 日常役割やSf 6 . 社会 生活機能の観点からは, 術後に治療疾患が起こら ないように健康を維持すること, 特に術後 1 〜 2 年や後期高齢者では, 目が離せないことが分かる. Sf 4. 体の痛みに留意すべき患者は, BMIが18以 下, 腫瘍患者でウロやコロの方, 術後 6 29年, 前期高齢者である. 逆にSf 5 . 活力で元気なのは, BMI正常, 有配偶者, 現在治療疾患なし, 原因疾 患が腸炎よりも腫瘍患者, イレオよりもウロやシ グマの方であるので，それ以外では活力が出るよ うな外科医のケアが望ましい. Sf 7. 心の健康で は, BMIで瘦身よりも肥満の方, 所属患者会が JOA, ないしは地域, 病院にあり, ウロやシグマ, 術後 $1 \sim 2$ 年よりも $6 \sim 29$ 年経過, 高齢の方が, 心理的問題に悩んでいない率が高いので, それ以 外の方には留意しておかなければならない. Sf 8. 精神的日常役割でも, 術後 $6 \sim 29$ 年経過した前期 高齢者では, 心理的理由で日常活動が妨げられる ことが低い. そういう傾向を知っておくと, 日常 診療の中で外科的ケアの参考になる.

1。ストーマ周囲皮膚について, 壮年よりも高 齢者は気にならなくなっているので, 留意してお く必要があろう。5，ストーマ付きの外見容姿が 気になりやすいのは, 女性, 術後 6 年未満, 青少 年であることが分かったので, 彼らには外科医か らの励ましが期待される。逆に，年を取るほど外 見容姿には拘らなくなっている.10. 衣服選択に ついても同様のことがいえる，6，ストーマに関 する羞恥心も, 男性や高齢者で少ないのではある が, 術前に医師も係わる説明が欠かせないことも 明らかになった。

7. ストーマ排泄物処理は, 男性, 有配偶者, ウ ロでは, 大変と感じていないが, そうでない対象 者に対しては術前から, 処理しやすいストーマを 造設する努力と看護師との協力関係が必須である.

当然かもしれないが，11. 困ったときに家族や 友人にケア援助してもらえるのは, 男性, 有配偶 者, 先天性疾患患者, 術後 $1 \sim 2$ 年が有意に高い ことも今回の調査で明らかになった．12. ストー マ外来や訪問看護の利用については, 術後 10 年以 上経過している方で, 術前の医師・看護師説明が 有意に高いことも忘れてはならない.
17. 個人入浴・シャワーに支障が少ないのは, 術後数年よりも20年以上経過してからであること， 18. 旅行・外泊支障が起こり難いのも10年以上経過 してからであることなども知っておくに值する. 20. 睡眠障害に陥りやすいのはウロ, イレオ, 炎 症性疾患, 術後数年, 45〜 59歳の方というのも留 意しておきたい.

25. パートナーへの好奇心低下の問題は, 配偶 者の有無や年齢が関係することは分かるが, 先天 性奇形患者に大きいことも知っておきたい. 26 . 性的魅力が低下したと感じるのは, 術後 $2 \sim 4$ 年 経過して，30～59歳が有意に大である．また， 27. 性機能では, 女性に悩みが少ないことは前述した が, 原因疾患が腹膜炎であった方に悩みが大きい. 女の性機能QOLスコア大という裏には, 日本女性 特有の性に対する関心が薄いという傾向の表れか もしれないので, 今後は西洋との比較が必要にな ろう。なお, 性別では, 衣服選択, 性機能, 経済 負担で有意差が出ているが, 性機能以外は男性で QOLスコアがよい.

28. 経済的自己負担が比較的少ないのは, 男性, BMI正常, 術後10年以上経過, 高齢者である.た だ，28．経済の偏相関でみると，1。周囲皮膚障 害, 5 . 外見容姿, 10 . 衣服の選択, 16 . 水分摂 取, 19. 運動支障, 20. 睡眠障害と関係があるの で，外科医としては周囲皮膚障害を起こすような 手術をしてはならないことが分かる。 また, 経済 的負担の多くが外科医の責任であるとはいいたく ないが, 特に女性, 若者, 瘦型の患者には最良の ストーマを造設するよう細心の注意が必要である.

治療中疾患の有無で活力や社会機能に有意差が 出るのは当然ながら, ストーマ原因疾患では活力 が腸炎に比べて腫瘍の方がQOLスコアは高い.つ まり, 腫瘍では再発しない限り問題は小さいが, 腸炎では術後もイレオの管理困難などの影響があ ると考えられる。

BMIでは活力に有意差が出ていることは, ストー マに関係なく肥満になれば活動が鈍るということ であろう。瘦身型が標準型やBMI＜35の者より活 力が落ちていることは当然かもしれないが, SRの 観点からも正常体型に是正する医療が必要なこと を意味している。 
原因疾患（Table 3 の 5 列目）では, 腫瘍と腸 炎の間に多くのQOL項目で有意差が出ているが, 良性疾患と悪性疾患という違いだけでなく，IBD が若年層に多いということも影響していることは, 同Table最右列や前編Table 3 から読夕取れる.

年齢層（Table 3 最右列）では, 年齢の低い方 がストーマに対するストレス（1．周囲皮膚状態， 2. ストーマ臭， 5 ．外見容姿， 6 。羞恥心， 10 . 衣服選択), 26. 性の魅力, 28. 経済負担などで 劣っているが, 年齢層が有意に低いイレオの影響 が強く出たとも考えられる.

術後年数（Table 3 の 7 列目）では, 年数が経 つ程QOLが安定してくるといえそうだが，一般的 に術後 3 力月以内とか65歳以上では, 社会要因又 コアの低いことが分かっている ${ }^{6)}$.

以上の様にオストメイトのQOL要素が具体的に 分かってきた。それを受けて，外科医としては何 を行うべきかを考えてみたい.17年前の旧版調査 結果でも分かっているように7), 自己管理度を基に して，ストーマに対する満足度（質問 $1 \sim 4,7$ ～9）やセクシュアリティ（25～27）をみると， セルフケアが可能な人はストーマ満足度が高く, 人任せにしておく者ではストーマ満足度が低い. つまり, 満足にセルフケアができるように導くの が，医療者の役目である。他人任せの者ではセク シュアリティも低かった. 前編Table 8 でも示し たように， 3 ．排泄物の装具漏れがあると，ストー マQOL（特に 4，9）や心理要因（特に6，20） や社会・経済性にも多大な影響を及ぼしているこ とが分かる。セルフケアや皮膚保護剤・装具の選 択もさることながら, 外科医はストーマ排泄物の 漏れが起こらないように, ストーマの造設部位, 大きさ，長さなどの術式を実施しなければならな い. 単に, 看護師に位置決め（サイトマーキング） をさせておくだけではなく，術前術後に一瞬でも 患者と行動を共にして，それが最適であることを 確認する責任がある。

QOL背景を踏まえた上で，入院前のICが行われ るようになるとよい. しかし，このQOL調査結果 で分かるように，ICはその外科医の義務だけでは 不十分であり，患者側が自主的に選択するイン フォームドチョイスでなければならないことを示
している，単に術式だけを選択してもらうのでは なく，その理由や背景も聞き出しておきたい.さ らには，ストーマを造設することにより，術後の 生活がどのように変わるか, して欲しいことや欲 しくないことなども語ってもらえるとよい，早期 に患者情報を共有して, それを知って初めてメス を持つことができるのである，ICは患者権利に関 する概念であり, 医師の一方通行的情報伝達であっ てはならない，患者に納得してもらわない限り， 換言すれば医師が患者を理解しない限り, 結果的 に「聞いていない」といわれることになる。その 一助として, たとえば, 医師が説明した後は, 研 修医や看護師に「どんな治療で，どれくらいの治 療効果が期待できるか. ストーマを付けると家庭 や社会生活はどうなるか? 人生で大切にしている ことは何か」などと訊かせて, 患者自ら言語化し てもらうことが肝要である．従来なら，ICでSRの ことを患者に理解してもらうだけでよかったが, 今や患者が納得したら, 術前からSRへの取り組み を始めなければならない.つまり, SRクリティカ ルパスの 1 例 $^{8}$ にあるように, 担当看護師と融合し て, オストメイトQOL向上にチーム貢献したいも のである. 医師は誰であってもストーマ造設術式 としては同じものであるが, 術前後のアプローチ 如何によって各術者独自の個性ある医療芸術にな りうる.

\section{結語}

外科医は, 術後患者の満たされていないニーズ を知って, 専門的ケアを施すことにより, 初めて 手術が完成した喜びを知るであろう。それには術 前から患者のQOLに関心を持ち, 看護師や関係者 と融合する中で, 外科医的ケアの発見と実践が期 待されている. 患者の問題点を読解して即対応で きるような外来診療とするため, 究極的（葉書大） QOL票の開発に取り組んでいる。

\section{謝 辞}

大阪市立総合医療センター看護部の本田優子氏, 国 立病院機構大阪医療センター看護部の深井照美氏, JOA医療顧問の先生方の御協力に厚く御礼申し上げる.

利益相反：なし 


\section{文献}

1）厚生労働省大臣官房統計情報部：身体障害者手帳 交付台帳登載数, 障害の種類, 年齢 (2区分) $\times$ 障害の程度, 登載状況別. 社会福祉行政報告例, 2016, p12

2) 進藤勝久：QOL調查について. 日本オストミー協 会誌 $271: 12 \&$ Supple 1-4, 2015

3）福原俊一, 鈴鴨よしみ：第 4 章SF-8のスコアリ ング法. SF- 8日本語版マニュアル第 2 版, 特定 非営利活動法人健康医療評価研究機構, 京都, 2012, p27-33

4）福原俊一, 鈴鴨よしみ：第 6 章各項目とサマリー スコアの国民標準值. SF-8 日本語版マニュアル 第 2 版, 特定非営利活動法人健康医療評価研究機 構, 京都, 2012, p47-71
5）進藤勝久：ストーマリハビリテーション学. 永井 書店, 大阪, 2010

6) Hien NT, Endo Y, Kawata Y, et al: The QOL of patients with a colostomy in 2 hospitals in Ho Chi Minh City of Vietnam and one hospital in Shiga prefecture of Japan - Evaluated by 36-Item Short Form survey. Asian Ostomy 8:2-6, 2014

7）進藤勝久：IV.得られた結果をどのようにベッドサ イドで活用するか 11）人工肛門. 新QOL調查と 評価の手引き一調査と解析の実際とベッドサイド の生かし方, メディカルレビュー社, 東京, 2001, p397-407

8）進藤勝久：表 4.ストーマリハビリテーションのク リニカルパスウェイ，ストーマリハビリテーショ ン学. 永井書店, 大阪, 2007, p11

\title{
Ostomates' QOL and Surgeon's Responsibility in Ostomy Surgery: Part 2. Analysis of the National Survey
}

\author{
Katsuhisa Shindo ${ }^{1)}$ and Sadanori Kamikawa ${ }^{2)}$ \\ ${ }^{1)}$ Kindai Medical Support Center \\ ${ }^{2)}$ Department of Urology, Osaka City General Medical Center
}

\begin{abstract}
Aim: A revised questionnaire has been applied for the national survey of ostomates, in order to examine any correlations between the background variables and the QOL. The results should help in surgeons' improving their surgical techniques and care for ostomates.

Methods: The data collected from 2200 nationwide ostomates were analyzed for the existence of correlations between each factor and the quality of life and to determine the influence of the stoma on the ostomates' QOL. The results were analyzed for statistical significance, and collated with clinical experience.
\end{abstract}

Results: Statistical analysis showed that the score for each physical, social and life variable was lower in ostomates in general health scoring. The scores for mental factors were slightly lower, and those for vitality and health feelings were higher. Scores for psychological distress and stoma-related problems were lower in JOA and other members, but not in non-members. Housekeeping economy was related to the ostomates' peristomal skin damage and difficulties during sports, sleep and/or clothing selections.

Conclusions: Surgeons should show interest in their ostomates' daily lives and social activities, which will enhance their awareness of the necessity to improve their surgical techniques and care for ostomates.

Key words: QOL, Ostomate, Colostomy, Urostomy, Stoma-Rehabilitation 